\title{
THE FIRST GERMAN GRAMMAR IN RUSSIA: CREATION AND SOURCES ${ }^{1}$
}

\author{
Nataliya V. Kareva \\ Institute for Linguistic Studies of the Russian Academy of Sciences, Saint Petersburg, Russia

\section{Evgeniy G. Pivovarov} \\ Saint Petersburg Branch of the Institute for the History of Natural Sciences and Technology \\ of the Russian Academy of Sciences, Saint Petersburg, Russia
}

\begin{abstract}
Die Teutsche Grammatica... by M. Schwanwitz (St. Petersburg, 1730) was the first German grammar printed in Russia. It was bilingual: Russian and German sections were parallel. The Russian text reflected the diversity and variability of the new, early $18^{\text {th }}$ century "civil" literary language. The article authors describe linguistic terminology of Schwanwitz's textbook, study editorial changes made during its creation and examples corpus used in the grammar, first of all, anthroponyms. Comparative analysis of the structure, content and illustrative material of Schwanwitz's grammar and Die deutsche Grammatica... by Charmyntes (Berlin, 1713) allows us to conclude that Charmyntes's grammar was not the only source of the academic textbook. In cases where Schwanwitz borrowed material from the German source, he critically rethought and rewrote the original. The authors disagree with the assertion outspoken in scientific literature that Schwanwitz's work was for the most part imitative to Die deutsche Grammatica... by Charmyntes and that the Berlin edition should be considered as a conductor of the Western model of grammatical description in Russia. Study of Die Teutsche Grammatica... creation allows to conclude that lack of its author's formal education case was atoned by rich practical experience, ability to learn a lot and quickly and obvious desire to become a philologist recognized by contemporaries.

Key words: German grammar, Academy of Sciences, M. Schwanwitz, Charmyntes, $18^{\text {th }}$ century, chronology, linguistic sources, linguistic terminology.

Citation. Kareva N.V., Pivovarov E.G. The First German Grammar in Russia: Creation and Sources. Vestnik Volgogradskogo gosudarstvennogo universiteta. Seriya 2. Yazykoznanie [Science Journal of Volgograd State University. Linguistics], 2019, vol. 18, no. 4, pp. 18-28. (in Russian). DOI: https://doi.org/10.15688/jvolsu2.2019.4.2

\section{ПЕРВАЯ В РОССИИ ГРАММАТИКА НЕМЕЦКОГО ЯЗЫКА: ИСТОРИЯ СОЗДАНИЯ И ИСТОЧНИКИ ${ }^{1}$}

\author{
Наталия Владимировна Карева \\ Институт лингвистических исследований РАН, г. Санкт-Петербург, Россия
}

Евгений Григорьевич Пивоваров

Санкт-Петербургский филиал Института истории естествознания и техники им. С.И. Вавилова РАН, г. Санкт-Петербург, Россия

Аннотация. В статье рассматривается первая напечатанная в России грамматика немецкого языка «Die Teutsche Grammatica...» М. Шванвица, вышедшая в 1730 г. в Санкт-Петербурге. Она была двуязычной: русская и немецкая части были даны параллельно, при этом русский текст отражал пестроту и вариативность нового «гражданского» литературного языка первой трети XVIII в. В статье подробно охарактеризованы лингвистическая терминология учебника, редакторские правки и корпус использованных примеров (прежде 
всего антропонимов). На основе сопоставительного анализа структуры, содержания и иллюстративного материала грамматики Шванвица и изданной в Берлине в 1713 г. «Die deutsche Grammatica...» Шарминта сделан вывод о том, что грамматика Шарминта была не единственным источником академического учебника. Результаты исследования показывают, что в тех случаях, когда Шванвиц заимствовал материал из немецкого издания, он критически переосмыслял и перерабатывал его. Эти данные опровергают бытующее в научной литературе утверждение о том, что работа Шванвица по большей части вторична по отношению к «Die deutsche Grammatica...» Шарминта.

Ключевые слова: грамматика немецкого языка, Академия наук, М. Шванвиц, Шарминт, XVIII век, хронология, лингвистические источники, лингвистическая терминология.

Цитирование. Карева Н. В., Пивоваров Е. Г. Первая в России грамматика немецкого языка: история создания и источники // Вестник Волгоградского государственного университета. Серия 2, Языкознание. 2019. - T. 18, № 4. - C. 18-28. - DOI: https://doi.org/10.15688/jvolsu2.2019.4.2

\section{«Россіискои юности въ пользу издана»: грамматика и ее автор}

Первой напечатанной в России грамматикой немецкого языка была «Die Teutsche Grammatica. Aus unterschiedenen Auctoribus zusammen getragen und der Russischen Jugend zum Besten heraus gegeben von dem Informatore der Teutschen Sprache bey dem St. Petersburgischen Gymnasio. НЊмецкая грамматика изъ разныхъ авторовъ собрана и россіискои юности въ пользу издана оть учителя нъмецкаго языка при Санкть Петербургскои гүмназіи», вышедшая первым изданием в 1730 г. в Санкт-Петербурге. Биография ее автора, Мартина Шванвица (?-1740) достаточно хорошо исследована [Блок, 1940а, с. 208-209; Дамен; Копелевич, 1977, с. 100, 151; Московкин, 2009; Хотеев, 2008, с. 72-73; Keipert, 1983, S. 81-82; Schröder, 1995, S. 141-143], хотя для читающей публики он известен, прежде всего, как основатель дворянского рода, исторические анекдоты о представителях которого собирал А.С. Пушкин, изучая историю Пугачевского бунта [Блок, 1940а; 1940б; Овчинников, 1991]. Нас же интересуют те факты его богатой событиями жизни, которые помогают понять, как происходило становление Шванвица - языковеда и переводчика.

Он родился в Торуни (нем. Thorn), городе, принадлежавшем тогда Королевству Польскому, но заселенному по преимуществу немцамипротестантами. Достаточно легко определить, в каком языковом окружении прошли его детские и юношеские годы. Известно замечание вестфальца Герхарда Фридриха Миллера:рассуждая о недостаточной образованности Шванвица, он называл его «пруссаком»².
В родном городе он учился в средней школе. Сейчас трудно определить, на каком языке велось преподавание, однако сохранилось свидетельство (стихотворение, сочиненное для отца) того, что к концу своего пребывания в ней он достаточно хорошо разговаривал и писал по-польски. Позднее, в 1720 г., то есть всего через два года после переезда в Россию, он уже работал переводчиком, и, как отмечают, владел немецким, латинским и русским. Вероятно, знание польского помогло ему быстро освоить язык новой родины. Он овладел им настолько хорошо, что уже в 1725 г. был нанят в качестве «информатора немецкого языка» в гимназию недавно образованной Академии наук (МАН, 1885, с. 142, 145), а в начале 1728 г. на него была возложена обязанность переводить на русский газеты «Санкт-Петербургские ведомости» и «Примечания к Ведомостям».

$\mathrm{B}$ «покорнейшей промемории» в «Императорского Величества Академию наук» от 18 января 1734 г. он так перечислял свои обязанности: «die ehre gehabt, der kayserlichen academie der wissenschaften von dem 1-sten september des verflossenen 1725 -sten jahres bis d. 22-sten januarii 1728 als informator in der teutschen sprache, bis an d. 13-ten februarii 1732 aber als corrector zu dienen; in welchen beyden officiis ich... nicht nur die advisen und remarqven ins russische übersetzet, sondern auch die, zur unterweisung der russischen jugend in der teutschen sprache gehörige grammatic durch den druck ediret, und über das, eine andere grammatic, durch hülfe welcher die teutschen die russische sprache erlernen können, bis ad verba verfertiget, und dabey an dem, durch den druck ausgegebenen lexicon die helfte ausgearbeitet...» 
(МАН, 1886, с. 435-436). - Я имел честь служить в Императорской Академии наук с 1 сентября прошедшего 1725-го года до 22 января 1728-го в качестве информатора немецкого языка, а до 13 февраля 1732-го года в качестве корректора; в обеих этих службах я... не только переводил на русский язык ведомости и примечания, но и к наставлению русского юношества немецкому языку принадлежащую грамматику в печати издал, и другую грамматику, посредством которой немцы могут выучить русский язык, до глагола привел, а кроме того, половину печатью выпущенного лексикона переработал (перевод наш. $-H$. K., $E$. П.). Названная им первой, а, следовательно, и наиболее важная среди его филологических работ «Die Teutsche Grammatica» стала основным учебником, использовавшимся во всех классах академической гимназии. Она была двуязычной: русский и немецкий тексты шли параллельно.

\section{«Впечатление курьеза»: лингвистическая терминология русской части учебника}

Кириллический текст первого издания «Немецкой грамматики» отражал пестроту нового «гражданского» литературного языка, формировавшегося в России в первой трети XVIII в. Орфография русской части учебника Шванвица исследовалась В.М. Живовым, который отмечал «безразборное» употребление в ней старых и новых флексий прилагательных, непоследовательное употребление окончаний Дат. п. мн. числа существительных, вариативность форм инфинитива и отсутствие унификации по ряду других морфологических признаков [Живов, 1996, c. $168 ; 2004$, с. 215,$371 ; 2017$, т. 2 , с. 996 , $1000,1008]$.

Лингвистическая терминология русской части работы также привлекала внимание ученых. На первый взгляд она производит «впечатление курьеза» [Клубков, 2011, с. 76]. Для номинации частей речи и грамматических категорий Шванвиц использовал транслитерированные латинские наименования, к которым в квадратных скобках дал русские переводы. См., например, начало главы «О прономин [:м'сстоименіи]»:
«Прономина суть 1. Персоналія [:персоналные:] 2. Посессива [:притяжателные:] 3. Релатива [:съсылающіеся напрежднюю в Сщь или персону:] 4. Демонстратива [:указателные:] 5. Интеррогатива [:вопросителные:] 6. Индефинита [:не опред女ленные]» (Шванвиц, 1730, с. 189).

Принцип этот, однако, непоследовательно соблюден в «Немецкой грамматике». Иногда перевод отсутствует [Baumann, 1973, S. 650; Keipert, 1984, S. 127; 137-139]: например, только латинизированными терминами обозначены лексико-семантические разряды числительных (кардиналные, ординалные, пропориіоналные, коллективы, дистрибутивы) и местоимений (прономенъ релативумъ и реципрокумъ). В других случаях, наоборот, автор предпочитает русские наименования: так, в пятой главе третьей части «О сгнтадূи» используется преимущественно термин причастіе, а его аналог партиципіумъ опускается [Keipert, 1984, S. 127].

За обилие латинизмов «Немецкую грамматику» критиковали: см., например, замечание С.К. Булича о «незнакомстве» Шванвица «с русской школьной грамматической терминологией» [Булич, 2018, с. 321; см. также Baumann, 1973, S. 650]. Однако, по всей видимости, эта особенность учебника была обусловлена практикой преподавания иностранных языков в академической гимназии. Обучение в ней начиналось с уроков немецкого, а использование латинизированных наименований должно было подготовить студентов к последующим занятиям другими языками [Хотеев, 2008, с. 69-70; Keipert, 1984, S. 125; Keipert, 2009, S. 394].

Возможно, Шванвиц также ориентировался на учебные традиции Германии, где в XVI-XVII вв. в преподавании родного языка использовалась латинская терминология, а немецкие наименования вводились в пояснениях [Дюбо, 2001, с. 52-64]. Так или иначе, он не только в немецкой части своей книги использовал латинские термины, сопровождаемые пояснениями на немецком, но и в кириллической воссоздал терминологическое двуязычие, характерное для немецких учебников той эпохи.

Перед сдачей книги в печать осенью 1728 г. русский текст Шванвица редактировался неким московским филологом. Об этом из- 
вестно из письма, направленного 8 октября 1728 г. обер-секретарем Сената Иваном Кирилловичем Кирилловым библиотекарю и секретарю Академии Иоганну Даниэлю Шумахеру:

«Зд ‘сь же еще приложена зачатая въ вашей типографіи грамматика нъмецкая с россійскою, въ которой н中которые малые поправки въ словенскихъ рьчахъ учинены чрезъ моего благодьтеля, зд ‘шней школы учителя, знающаго латинскую, греческую и словенскую грамматику, риторику и философію» (МАН, 1885, с. 404).

Ответ Шумахера Кириллову от 28 октября свидетельствует о том, что «здњшней школы учитель» поправил, в первую очередь, русскую терминологию учебника:

«Господину Швановицу оную поправку, которую отъ васъ получилъ, показывалъ... яко: въ третьей страниц中, вмЊсто “сочиненіи словъ” “краснорьчіе”; такожде на иномъ мъст中, вмЊсто: "писмяни гласнаго" - "самогласное" находится, и иная, симъ подобная» (МАН, 1885, с. 405-406).

Правка была принята. В печатном варианте «Немецкой грамматики» мы находим краснор ъчіе как аналог термина синтад̆исъ и самогласные писмена в качестве перевода вокалесъ. Однако несколько лет спустя отброшенные редактором в 1728 г. русские термины были использованы в незаконченной рукописной «Compendium grammaticae russicae», над которой в 1731 г. работали Шванвиц, Василий Евдокимович Адодуров и другие академические сотрудники. Эта грамматика русского языка была написана по-немецки с использованием латинской и русской терминологии: с помощью сочетания $p$ tчей сочиненіе в ней переводятся лексемы Wort=Fügung и Syntaxis [Keipert, Huterer, 2002, S. 137]. Термины гласные и самогласныле функционируют как синонимы и выступают в качестве аналогов немецкого selbst lautende и латинского Vocales [Keipert, Huterer, 2002, S. 137].

\section{«Правописаніе, истязаніе словъ, краснор ччіе, удареніе»: грамматика Шванвица и учебник Шарминта}

В нашей статье мы хотели бы обратиться к немецкой части работы Шванвица, в меньшей степени привлекавшей внимание исследователей, нежели ее кириллический текст. В 2002 г. К. Кох высказала предположение, что в основу грамматики, созданной Шванвицем, легла изданная в Берлине в 1713 г. «Die deutsche Grammatica, Aus Unterschiedenen Autoribus zusammen gebracht / Und Der in Deutschland Studierenden Rußischen Nation zum besten / In einem Compendio herausgegeben von Charmyntes» [Koch, 2002, S. 326].

Связь этих двух трудов отмечалась еще в справочных изданиях XVIII в. Элиас Каспар Рейхард в «Versuch einer Historie der deutschen Sprachkunst», в разделе, посвященном Шарминту, писал о двуязычном учебнике «Die deutsche Grammatik, aus unterschiedenen Auctoribus zusammengetragen», вышедшем вторым изданием в 1734 г. в Санкт-Петербурге для нужд гимназии [Reichard, 1747, S. 491]. Видимо, речь шла о втором издании грамматики Шванвица, подготовленном Адодуровым, и Рейхарду было известно, что работа Шарминта легла в основу использовавшегося в академической гимназии пособия. Иоганн Андреас Фабрициус в «Abriss einer allgemeinen Historie der Gelehrsamkeit», ссылаясь на Якоба Пауля фон Гундлинга ${ }^{3}$, писал о вышедшем в Петербурге в 1731 г. варианте труда Шарминта [Fabricius, 1752, S. 147]. Имелось в виду, вероятнее всего, подготовленное в 1730 г. первое издание грамматики Шванвица, поскольку по данным «Сводного каталога русской книги гражданской печати...», других учебников немецкого языка в 1730-е гг. в Петербурге не издавалось (СK XVIII в., т. 5, с. 8).

Тем не менее до настоящего времени не было проведено последовательное сравнение двух текстов [Djubo, 2003, S. 454; Lexicon grammaticorum..., 2009, vol. 1, p. 492]. Сохранилось три экземпляра «Die deutsche Grammatica»: два из них находятся в Санкт-Петербурге (Библиотека Академии наук, Российская национальная библиотека), один - в Ростоке (Universitätsbibliothek Rostock). Пользуясь экземпляром БАН, мы сопоставили первое издание труда Шванвица и «Die deutsche Grammatica» Шарминта.

Оба учебника открываются определением грамматики и ее четырех частей: 1. Opєографia, правописаніе (Orthographia, 
die Rechtschreibung); 2. Етимологіа, истязаніе словъ (Etymologia, die Wort = Forschung); 3. Синтазииь, краснор tuie (Syntaxis, die Wort $=$ Fügung); 4. Просодіа, удареніе словъ (Prosodia, die Thon = Sprechung). Сопоставление даже первых фраз, с небольшими вариациями повторяющихся в ряде немецких трактатов о языке XVI и начала XVII в. [Дюбо, 2001, с. 167-173], показывает, что Шванвиц осуществлял стилистическую правку текста Шарминта: если у Шванвица грамматика это «еine Kunst, rein zu reden und recht zu schreiben» - «художество, право глаголати и пісати» (Шванвиц, 1730, с. 2-3) (в качестве перевода немецкого текста Шванвица здесь и далее приводятся соответствующие цитате фрагменты из кириллической части учебника), то у Шарминта - «eine Wissenschaft rein zu reden / und ordentlich zu schreiben» (Charmyntes, 1713, S. 1) - «наука чисто говорить и изрядно писать» (здесь и далее перевод цитат из книги Шарминта наш. $-H . K ., E$. П.). Кроме того, Шванвиц существенно расширяет первую часть грамматики, посвященную орфографии. Если у Шарминта немецкие правила чтения изложены кратко, то в грамматике Шванвица произношению немецких слов посвящены десятки страниц: рассмотрены основные правила правописания, использование строчных и прописных букв, употребление знаков препинания, отдельным списком даны немецкие слова-омофоны с русским и латинским переводом.

Вторая часть в каждом из учебников посвящена этимологии, то есть морфологии в современном понимании. Толкование систематики частей речи и свойственных им грамматических категорий являлось основой любого лингвистического описания национального языка в Европе в XVI-XVII вв. и опиралось на уже разработанную терминологию, поэтому неудивительно, что у обоих авторов эта часть - наиболее объемная. Следуя традиции эмпирических немецких грамматик XVII в., Шарминт и Шванвиц выделяют девять частей речи (Partes Orationis) - 1. apтикулусъ, иленъ (Articulus); 2. номенъ, имя (Nomen); 3. прономенъ, м tстоим tніе (Pronomen); 4. вербумь, глаголь (Verbuт); 5. nартиципіумь, участіе (Participium); 6. адвербіумъ, наречіе (Adverbium); 7. препозииіа, предлогъ (Praepositio);
8. конъюнкиіа, союзъ (Conjunctio); 9. інтер ткиіа, междом $\mathbf{k m i e ~ ( I n t e r j e c t i o ) . ~ З а - ~}$ тем Шванвиц вводит общие для всех частей речи категории: сneuiecъ, видъ (Species) и фигура, начертаніе (Figura), а также свойственные только изменяемым частям речи: аналогія, правилное (Analogia), аномалія, неправилное (Anomalia) и нумерусъ, число (Numerus). В учебнике Шарминта для изменяемых частей речи вводится также категория лица (Persona).

Рассматривая имена, Шванвиц и Шарминт вводят такие категории: генусъ, родъ (Genus); казусъ, падежь (Casus) и деклинація, склоненіе (Declinatio). Разделы, перечисляющие группы существительных мужского, женского и среднего родов, текстуально совпадают, однако Шванвиц добавляет примеры, содержащие отсылки к русским реалиям например, слова Rubel и Altin как примеры существительных мужского рода в дополнение к заимствованным из немецкого учебника Thaler и Ducat (Charmyntes, 1713, S. 5; Шванвиц, 1730, с. 132).

Шванвиц выделяет пять падежей - номинативусъ, имянителныл (Nominatiuиs); генетивусъ, родителныли (Genetiuиs); дативусъ, дателныи (Datiuиs); аккузативусъ, винителныи (Accusatiuиs); вокативусъ, звателныли (Vocatiuus) - и делает специальное примечание относительно шестого Аблативусъ, относителныи (Ablatiuиs), выделяемого Шарминтом:

«In dem Lateinischen hat man noch den Ablatiuum, welchen auch andere in ihren Teutschen Grammaticis beybehalten, wir aber alhier ausgelassen, weil er vom Datiuo eben so wenig, als im Griechischen unterschieden werden kan, und man doch die Jugend mit Weitläufftigkeiten nicht beschweren wil» «Въ Латинскомъ язык' им'ется еще Аблативусъ [:относителныи:] которыи такожде и протчіе н'ммцы въ своихъ граматикахъ употребляютъ, но мы онои здњсь того ради оставляемъ, понеже онъ съ дативомъ такъ, какъ въ Греческомъ язык' ни какои разности не им'етъ, а молодыхъ людеи съ пространствами утруждать нехотимъ» (Шванвиц, 1730 , c. $142-143)$.

Различия в трактовке Ablatiuus у Шванвица и Шарминта связаны, очевидно, с тем, что в немецких грамматиках XVI-XVII вв. существовало два подхода к падежной клас- 
сификации - семантический и формальный. Если представители первого направления например, Вольфганг Ратке, ориентируясь на латинскую традицию, выделяли шесть падежей, то представители второго - в их числе Альберт Элингер - под влиянием идей французского грамматиста Пьера де ля Раме и его последователей [Михайлова, 2008; BrevaClaramonte, 1983, p. 72-81], отказывались от выделения формально не выраженного в немецком шестого падежа [Дюбо, 2001, с. 221234; Jellinek, 1914, S. 190-193].

Как и Шарминт, Шванвиц выделяет артикуль дефинитусъ, совериенныи (Articulus Definitivus) и артикуль унитатисъ, несовершенныи (Articulus Unitatis); разделяет номенъ, имя (Nomen) на субстантивумъ, суще ствителное (Substantiuum) и ад вктивумь, прилагателное (Adiectiuum); подразделяет субстантивумь на пропріумь, собственное (Proprium) и аппеллативумь, общзее, (Appellatiuum); мобіле, прем 中няюшееся (Mobile) и иммобиле, непрем 'няюшееся (Immobile); вводит три типа склонения существительных и четвертый тип - склонение прилагательных; рассматривает лексикограмматические разряды числительных, а также существительные, которые «токмо число множественное» и «токмо число единственное имњютъ» (Шванвиц, 1730, с. 185, 187). Здесь снова следует отметить текстуальные совпадения между двумя учебниками. Шванвиц, однако, заменяет примеры на другие, ориентированные на читателя - жителя России. См., например, имена членов царской семьи Peter, Catharina и топонимы Sanct-Petersburg, Riga, Newa в качестве примеров имен собственных вместо Stephanus, Rhein, Berlin, Elbe, Kastenburg из берлинского издания (Шванвиц, 1730, с. 184; Charmyntes, 1713, S. 32).

За разделом, посвященным разрядам местоимений и их склонению, в «Немецкой грамматике» следует раздел «Von dem Participio. O партиципіи (участіи)». Шванвиц описывает причастия после имен, так как им свойственны категории рода, числа и падежа, однако указывает, что «партиціпія... отъ вербовъ происходятъ» (Шванвиц, 1730, с. 205). У Шарминта причастие рассмотрено как «глагольное имя» (Nomen Verbale), которое «ein Theil vom
Nomine, und ein Theil vom Verbo annimt» (Charmyntes, 1713, S. 60) («принимает часть от имени и часть от глагола»).

Раздел, посвященный глаголу - наиболее объемный в «Немецкой грамматике». У Шванвица и Шарминта глаголь, вербумь (Verbum) разделяется на персоналное, личное (Personale) и імперсоналное, безличное (Impersonale), вводятся категории персона, лице (Persona); нумерусъ, число (Numerus); темпусь, время (Тетриs); конюгація, спряжение (Coniugatio), генусъ, залогъ (Genus); модусъ, наклоненіе (Modus). Вопрос о том, сколько наклонений следует выделять в немецком языке, неоднократно поднимался в немецких грамматиках XVI-XVII вв. [Дюбо, 2001, с. 266-292; Jellinek, 1914, S. 312-320]; Шарминт и Шванвиц выделяют ${ }^{4}$ их четыре: індикативусъ, изъявителнои (Indicatiuиs); імперативусь, повелителнои (Imperatiuus); конюнктивусъ, сосглагателнои (sic!) (Conjunctiuus); інфинитивусъ, неопред (Infinitiuus), в парадигмах вводят также суnинумъ (Sиріпит) и герундіумъ, д ъепричастіе (Gerundium). Кроме того, оба автора выделяют три залога: активумъ, д қиствителное (Actiuит); пассивумь, страдателное (Passiuиm); неитрумь, среднее (Neutrum) и предлагают трехступенчатую классификацию глагольных времен. Они выделяют презенсъ, настоящііи (Praesens); претеритумъ, прошедшіи (Praeteritum) и футурумь, будущіи (Futurum); вводят две разновидности будущего - футурумъ примумъ, первое (Futurum Primum) и футурумь секундумь, второе (Futurum Secundum) - и три разновидности прошедшего времени імперфектумь, несовершенно прошедшее (Imperfectum); перфектумь, совершенно промедшее (Perfectum); плусквамь перфектумь, прешедшее пресовершенное (Plusquamperfectum), последнего также выделяется три разновидности. Далее даны парадигмы вербовъ аудалиарныхъ, помоществителныхъ, то есть вспомогательных глаголов (Verba Auxiliares); парадигмы глаголов первого, второго и третьего спряжений, а также со аудалиарныхъ, то есть модальных глаголов (Verba Nebenauxiliares); рассмотрены верба композита, сложенные вербы (Verba Composita) и верба имперсоналные, безлич- 
ные (Verba Impersonalia). После этого в «Немецкой грамматике» в виде списка представлены неправильные глаголы - у Шарминта менее подробный список дан в конце в виде приложения к грамматике.

Следующие разделы в учебниках посвящены адвербіямъ, наречіямъ (Adverbium) и препозичіямъ, предлогамъ (Praepositio). Оба автора выделяют семнадцать семантических классов наречий, разделяют предлоги на сепарабилные, отделяюшіеся (Separabiles) и инсепарабилные, неотделяющіеся (Inseparabiles), но в целом раздел о предлоге у Шванвица содержит более подробную, чем в учебнике Шарминта, информацию. Заключают вторые части обеих грамматик разделы о конюнкціи, союз (Coniunctio) и интер ъкціи, междометіи (Interiectio) - тексты этих разделов различаются.

Третья часть грамматик посвящена синтаксису. Если раздел о синтаксисе артиклей из берлинского учебника практически без изменений воспроизведен в петербургском издании, то раздел о синтаксисе имени существенно переработан, в частности, заменены примеры, содержащие антропонимы: как иллюстрация сочетаний имен собственных с порядковым числительным у Шванвица даны Peter der Erste, Carl der Zwölfte, a у Шарминта - Carl der Sechste, Philip der Fünffte (Шванвиц, 1730, с. 354-355; Charmyntes, 1713, S. 71). Раздел о синтаксисе местоимений из немецкого источника воспроизведен у Шванвица с небольшими изменениями. Имеют сходство и разделы о синтаксисе глагола, однако Шванвиц заменяет примеры на другие, ориентированные на русские реалии. Так, предложение «Königsberg liegt von Dantzig zwanzig Meilen» (Charmyntes, 1713, S. 89) («OT Кенигсберга до Данцига 20 миль») заменено на «Moscau liegt von St. Petersburg 765 Würste» - «Оть Москвы до Санкть Петербурга 765 версть» (Шванвиц, 1730, с. 384 385), a фраза «Ich habe das Pferd um oder für fünffzig Thlr. gekaufft» (Charmyntes, 1713, S. 89) («Я купил лошадь за пятьдесят талеров») - на «Ich habe das Pferd um oder für fünffzig Rubel gekaufft» - «Я купиль сію лошадь за пятдесять рублевъ» (Шванвиц, 1730, c. 384-385). Рассматривая синтаксис причастий, Шванвиц копирует порядок расположения материала у Шарминта и описывает при- частие после глагола. Что же касается разделов, посвященных синтаксису наречий, предлогов, союзов и междометий, то в изложении Шванвица текст предшественника сокращен.

Посвященная просодии четвертая часть книги Шарминта была подвергнута существенному сокращению в «Немецкой грамматике». В частности, в ней отсутствует завершающий берлинский учебник раздел «Von den Figuris Orthographicis».

\section{«Изъ разныхъ авторовъ собрана»: заключение}

Со всей очевидностью, «Die deutsche Grammatica» была не единственным источником академического учебника, как на это и указал в названии сам автор. Нельзя согласиться с утверждением К. Кох о том, что работа Шванвица по большей части вторична по отношению к книге Шарминта и что, таким образом, берлинское издание 1713 г. следует считать проводником западной модели грамматического описания в Россию [Koch, 2002, S. 223, 326, 328]. Сопоставление двух текстов показывает, что в тех случаях, когда Шванвиц заимствовал из материал из немецкого учебника, он критически переосмыслял и перерабатывал его.

Кто же был «учитель н'ымецкаго языка при Санкть Петербургскои ггмназіи» и как мог «пруссак без образования», незнакомый с «школьной грамматической терминологией», написать популярный учебник, выходивший не только многократно, но и большими для того века тиражами (CK XVIII, т. 3, с. 373)? Только ли нехватка отечественных кадров заставила администрацию Академии обратиться к нему как к специалисту, способному быстро подготовить беспрецедентное в то время издание? Следует ли считать его эпигоном, лишенным какой-либо творческой самостоятельности?

Очевидно, что нет. Снобизм Миллера, сына ректора гимназии, учившегося в престижном Лейпцигском университете, общеизвестен и, в общем, понятен. К середине 1730-х гг. «выскочка» и «самоучка» из семьи провинциального шорника стал ректором немецкого отделения Академической гимназии, членом авторитетного Российского собрания, автором 
и переводчиком нескольких изданных книг, а будущий академик, лишившись покровительства всесильного Шумахера, вынужден был в это время «исследовать» Сибирь в составе «Второй Камчатской экспедиции». Внимательное изучение обстоятельств создания «Die Teutsche Grammatica» позволяет нам заключить, что отсутствие формального образования в случае Шванвица искупалось богатым практическим опытом, способностью много и быстро учиться и, наконец, очевидным желанием стать признанным современниками филологом.

\section{ПРИМЕЧАНИЯ}

${ }^{1}$ Работа Н.В. Каревой выполнена при финансовой поддержке РФФИ, проект № 18-012-00321А «Антропонимы в русской словесной культуре XVIII века (историко-литературный и лингвистический аспекты)».

The reported study of N.V. Kareva was funded by RFBR, project no. 18-012-00321A “Anthroponyms in the $18^{\text {th }}$-Century Russian Verbal Culture (Historical, Literary and Linguistic Aspects)".

${ }^{2}$ «Man glaubte, für die deutsche sprache sey der informator Schwanewitz, ein preusse, der nicht studirt hatte, zulänglich» [MAН, 1890, с. 170] - Полагали, что для перевода с немецкого подойдет информатор Шванвиц, пруссак без образования (перевод наш. $-H$. K., E. П.).

${ }^{3}$ Несмотря на то, что оба грамматиста говорят о четырех наклонениях, только у Шванвица сформулированы формально-семантические критерии их выделения. То же касается залогов и глагольных времен: краткие правила из труда Шарминта дополнены в учебнике Шванвица развернутыми семантическими дефинициями.

${ }^{4}$ Фабрициус приводит сокращенную ссылку на книгу Гундлинга - C.H.L.I., S. 131. До настоящего момента нам не удалось обнаружить эту работу в списке известных трудов Гундлинга.

\section{СПИСОК ЛИТЕРАТУРЫ}

Блок Г. П., 1940а. Путь в Берду (Пушкин и Шванвичи) // Звезда. № 10. С. 208-217.

Блок Г. П., 1940б. Путь в Берду (Пушкин и Шванвичи) // Звезда. № 11. С. 139-149.

Булич С. К., 2018. Очерк истории языкознания в России ХІІІ-ХІХ вв. Изд. стер. М. : Либроком. 1104 с.

Дамен К. Schwanwitz // Электронная база данных Германского исторического института в Мос- кве «Изучение языков Российской империи в XVIII в.». URL: http:/quellen-perspectivia.net/ $\mathrm{ru} /$ langlearninginruss/Schwanwitz (дата обращения: 28.08.2019).

Дюбо Б. А., 2001. Рационализм и эмпиризм в немецких грамматических трудах XVI-XVIII вв. СПб. : Изд-во С.-Петерб. ун-та. 408 с.

Живов В. М., 1996. Язык и культура в России XVIII века. М. : Яз. рус. культуры. 591 с.

Живов В. М., 2004. Очерки исторической морфологии русского языка XVII-XVIII веков. М. : Яз. слав. культуры. 656 с.

Живов В. М., 2017. История языка русской письменности : в 2 т. М. : Рус. фонд содействия образованию и науке. Т. 1.816 с. ; Т. 2. 480 с.

Клубков П. А., 2011. Формирование петербургской традиции лингвистической русистики (XVIII начало XIX в.). СПб. : Изд-во С.-Петерб. ун-та. $162 \mathrm{c}$.

Копелевич Ю. Х., 1977. Основание Петербургской Академии наук. Л. : Наука. 212 с.

Михайлова Е. Н., 2008. Теория частей речи в трудах Пьера де ла Раме (к вопросу о маргинальных парадигмах в истории языкознания) // Альманах современной науки и образования. № 8 (15), ч. 2. С. 122-125.

Московкин Л. В., 2009. Из истории преподавания иностранных языков в XVIII веке: Мартин Шванвиц // Проблемы современной филологии и лингводидактики. СПб. : Изд-во РГПУ им. А.И. Герцена. Вып. 3. С. 172-176.

Овчинников Р. В., 1991. Записи Пушкина о Шванвичах // Пушкин. Исследования и материалы. Л. : Наука. С. 235-245.

Хотеев П. И., 2008. Немецкая книга и русский читатель в первой половине XVIII века. СПб. : БАН. $374 \mathrm{c}$.

Baumann H., 1973. Adodurovs Bedeutung für Entwicklung der russischen Literatursprache // Zeitschrift für Slavistik. Vol. 18, iss. 1. S. 646-652.

Breva-Claramonte M., 1983. Sanctius' Theory of Language. A contribution to the history of Renaissance Linguistics. Amsterdam; Philadelphia : John Benjamins Publishing Company. 294 p.

Djubo B., 2003. Koch K.: Deutsch als Fremdsprache im Russland des 18. Jahrhunderts. Berlin / New York : Walter de Gruyter 2002. XVIII, 456 S. // Zeitschrift für Slavische Philologie. Vol. 62, iss. 2. S. 451-454.

Fabricius J. A., 1752. Abriss einer allgemeinen Historie der Gelehrsamkeit : in $3 \mathrm{Bdn}$. Leipzig : Weidmannische Buchhandlung. Bd. 1.945 S.

Jellinek M. H., 1914. Geschichte der neuhochdeutschen Grammatik von dem Anfängen bis aufAdelung. Zweiter Halbband. Heidelberg : Carl Winter's Universitätsbuchhandlung. $504 \mathrm{~S}$. 
Keipert H., 1983. Die Peterburger «Teutsche Grammatica» und die Anfänge der Russistik in Russland // Studia Slavica in honorem viri doctissimi Olexa Horbatsch. Teil 3: Lomonosov und grammatische Beschreibung im 18. Jahrhundert. München : O. Sagner. S. 77-140.

Keipert H., 1984. Die lateinisch-russische Terminologie der Petersburger «Teutschen Grammatica» von 1730 // Wiener slavistischer Almanach. Bd. 13. S. 121-139.

Keipert H., 2009. Die Latinisierung der grammatischen Terminologie des Russischen // Text - SpracheGrammatik. Slavisches Schrifttum der Vormoderne. Festschrift für Eckhard Weiher. München ; Berlin : O. Sagner. S. 387-400.

Keipert H., Huterer A., 2002. Compendium Grammaticae Russicae (1731). Die erste Akademie-Grammatik der russischen Sprache. Herausgegeben von $\mathrm{H}$. Keipert in Verbindung mit Andrea Huterer. München : Verlag der Bayerische Akademie der Wissenschaft. 219 S.

Koch K., 2002. Deutsch als Fremdsprache im Russland des 18. Jahrhunderts. Berlin ; N. Y. : Walter de Gruyter. 456 S.

Lexicon grammaticorum: a bio-bibliographical companion to the history of linguistics, 2009. In 2 vols. / ed. by H. Stammerjohann. Tübingen : Niemeyer. 1692 p.

Reichard E. C., 1747. Versuch einer Historie der deutschen Sprachkunst. Hamburg : Bey Johann Adolph Martini. $496 \mathrm{~S}$.

Schröder K., 1995. Biographisches und bibliographisches Lexicon der Fremdsprachenlehrer des deutschsprachigen Raumes, Spätmittelalter bis 1800: in 6 Bdn. Augsburg : Augsburger I \& I Schriften. Bd. 4.469 S.

\section{ИСТОЧНИКИ}

MAH - Материалы для истории Императорской Академии наук : в 10 т. СПб. : Тип. Имп. акад. наук. Т. 1. 1885. 732. с. ; Т. 2. 1886. 886 с.; Т. 6. $1890.638 \mathrm{c}$.

CK XVIII - Сводный каталог русской книги гражданской печати XVIII века. 1725-1800 : в 6 т. М. : Изд. Гос. б-ки СССР им. В.И. Ленина, 19621976. Т. 5.300 с.

Шванвиц - Шванвиц M. Die Teutsche Grammatica. Aus unterschiedenen Auctoribus zusammen getragen und Der Russischen Jugend zum Besten heraus gegeben von dem Informatore der Teutschen Sprache bey dem St. Petersburgischen Gymnasio = НҺмецкая грамматика изъ разныхъ авторовъ собрана и россіискои юности въ пользу издана отъ учителя нъмецкаго языка при Санкть
Петербургскои гґмназіи. СПб. : Тип. Акад. наук, 1730. $13 \mathrm{c}$.

Charmyntes - Die deutsche Grammatica, Aus Unterschiedenen Autoribus zusammen gebracht... / Hrsg. von Charmyntes. Berlin, 1713.120 S.

\section{REFERENCES}

Blok G.P., 1940a. Put v Berdu (Pushkin i Shvanvichi) [The Way to the Berda (Pushkin and the Shvanvichy)]. Zvezda, no. 10, pp. 208-217.

Blok G.P., 1940b. Put v Berdu (Pushkin i Shvanvichi) [The Way to the Berda (Pushkin and the Shvanvichy)]. Zvezda, no. 11, pp. 139-149.

Bulich S.K., 2018. Ocherk istorii yazykoznaniya $v$ Rossii XIII-XIX vv. [Essay on History of Linguistics in Russia]. Moscow, Librokom Publ. 1104 p.

Damen K. Schwanwitz. Elektronnaya baza dannykh Germanskogo istoricheskogo instituta $v$ Moskve «Izuchenie yazykov Rossiiskoi imperii $v$ XVIII v.» [Electronic Database of German Historical Institute in Moscow "Studying the Languages of the Russian Empire in the $18^{\text {th }}$ Century"]. URL: http://quellen-perspectivia.net/ $\mathrm{ru} /$ langlearninginruss/Schwanwitz (accessed 28 August 2019).

Dyubo B.A., 2018. Ratsionalizm i empirizm $v$ nemetskikh grammaticheskikh trudakh XVI$X V I I I v v$. [Rationalism and Empiricism in German Grammatical Treaties of the $16^{\text {th }}-18^{\text {th }}$ Centuries]. Saint Petersburg, Izd-vo Sankt-Peterburgskogo universiteta. $408 \mathrm{p}$.

Zhivov V.M., 1996. Yazyk i kultura v Rossii XVIII veka [Language and Culture in $18^{\text {th }}$ Century Russia]. Moscow, Yazyki russkoy kultury Publ. 591 p.

Zhivov V.M., 2004. Ocherki istoricheskoy morfologii russkogo yazyka XVII-XVIII vekov [Essays on the Historical Morphology of the Russian Language of the $17^{\text {th }}-18^{\text {th }}$ Centuries]. Moscow, Yazyki slavyanskoy kultury Publ. 656 p.

Zhivov V.M., 2017. Istoriya yazyka russkoy pismennosti: in $2 \mathrm{t}$. [The History of the Language of Russian Writing System. In 2 vols.]. Moscow, Russkiy fond sodeistviya obrazovaniyu i nauke. Vol. 1. 816 p.; Vol. 2. 480 p.

Klubkov P.A., 2011. Formirovanie peterburgskoy traditsii lingvisticheskoy rusistiki (XVIII nachalo XIX v.) [Forming of Petersburg Tradition of the Russian Lnguistics (18 ${ }^{\text {th }}-$ Early $19^{\text {th }}$ Centuries)]. Saint Petersburg, Izd-vo SanktPeterburgskogo universiteta. $162 \mathrm{p}$.

Kopelevich Yu.Kh., 1977. Osnovanie Peterburgskoy Akademii nauk [Foundation of Saint Petersburg 
Academy of Sciences]. Leningrad, Nauka Publ. $212 \mathrm{p}$.

Mikhaylova E.N., 2008. Teoriya chastey rechi v trudakh Pera de la Rame (k voprosu o marginalnykh paradigmakh $\mathrm{v}$ istorii yazykoznaniya) [Theory of Parts of Speech in the Works of Pierre de La Rame (To the Issue of Marginal Paradigms in the History of Linguistics)]. Almanakh sovremennoy nauki $i$ obrazovaniya, no. 8(15), part 2, pp. 122-125.

Moskovkin L.V., 2009. Iz istorii prepodavaniya inostrannykh yazykov v XVIII veke: Martin Shvanvits [From the History of Teaching Foreign Languages in Russia in the $18^{\text {th }}$ Century: Martin Schwanwitz]. Problemy sovremennoy filologii i lingvodidaktiki, no. 3, pp. 172-176.

Ovchinnikov R.V., 1991. Zapisi Pushkina o Shvanvichakh [Pushkin's Notes of the Shvanvichy]. Pushkin. Issledovaniya $i$ materialy [Pushkin. Research and Materials]. Leningrad, Nauka Publ., pp. 235-245.

Khoteev P.I., 2008. Nemetskaya kniga i russkiy chitatel v pervoy polovine XVIII veka [German Book and Russian Reader in the First Half of the $18^{\text {th }}$ Century]. Saint Petersburg, BAN Publ. 374 p.

Baumann H., 1973. Adodurovs Bedeutung für Entwicklung der russischen Literatursprache. Zeitschrift für Slavistik, no. 18, S. 646-652.

Breva-Claramonte M., 1983. Sanctius' Theory of Language. A Contribution to the History of Renaissance Linguistics. Amsterdam, Philadelphia, John Benjamins Publishing Company. 294 p.

Djubo B.A., 2003. Koch, K.: Deutsch als Fremdsprache im Russland des 18. Jahrhunderts. Berlin, New York, Walter de Gruyter 2002. XVIII, 456 S. Zeitschrift für Slavische Philologie, vol. 62, no. 2, S. 451-454.

Fabricius J.A., 1752. Abriss einer allgemeinen Historie der Gelehrsamkeit. In $3 \mathrm{Bdn}$. Leipzig, Weidmannische Buchhandlung, Bd. 1.945 S.

Jellinek M.H., 1914. Geschichte der neuhochdeutschen Grammatik von dem Anfängen bis auf Adelung. Zweiter Halbband. Heidelberg, Carl Winter's Universitätsbuchhandlung. $504 \mathrm{~S}$.

Keipert H., 1983. Die Peterburger "Teutsche Grammatica" und die Anfänge der Russistik in Russland. Studia Slavica in honorem viri doctissimi Olexa Horbatsch. Teil 3: Lomonosov und grammatische Beschreibung im 18. Jahrhundert. München, O. Sagner, S. 77-140.

Keipert H., 1984. Die lateinisch-russische Terminologie der Petersburger "Teutschen Grammatica" von 1730. Wiener slavistischer Almanach, Bd. 13, S. 121-139.

Keipert H., 2009. Die Latinisierung der grammatischen Terminologie des Russischen. Text-SpracheGrammatik. Slavisches Schriftum der
Vormoderne. Festschrift für Eckhard Weiher. München, Berlin, O. Sagner, S. 387-400.

Keipert H., Huterer A., 2002. Compendium Grammaticae Russicae (1731). Die erste Akademie-Grammatik der russischen Sprache. Herausgegeben von H. Keipert in Verbindung mit Andrea Huterer. München, Verlag der Bayerische Akademie der Wissenschaft. 219 S.

Koch K., 2002. Deutsch als Fremdsprache im Russland des 18. Jahrhunderts. Berlin, New York, Walter de Gruyter. $456 \mathrm{~S}$.

Stammerjohann H., ed., 2009. Lexicon Grammaticorum: A Bio-Bibliographical Companion to the History of Linguistics: In 2 Vols. Tübingen, Niemeyer. 1692 p.

Reichard E.C., 1747. Versuch einer Historie der deutschen Sprachkunst. Hamburg, Bey Johann Adolph Martini. 496 S.

Schröder K, 1995. Biographisches und bibliographisches Lexicon der Fremdsprachenlehrer des deutschsprachigen Raumes, Spätmittelalter bis 1800:in $6 \mathrm{Bdn}$. Augsburg, Augsburger I \& I Schriften, Bd. 4.469 S.

\section{SOURCES}

Materialy dlya istorii Imperatorskoy Akademii nauk: $v 10 t$. [Materials for the History of the Imperial Academy of Sciences. In 10 Vols.]. Saint Petersburg, Tipografiya Imperatorskoy akademii nauk, vol. 1, 1885. 732 p.; Vol. 2, 1886. 886 p.; Vol. 6, 1890.638 p.

Svodnyy katalog russkoy knigi grazhdanskoy pechati XVIII veka. 1725-1800: v 6 t. [Union Catalogue of Russian Books of Civil Print of the $18^{\text {th }}$ Century. 1725-1800. In 6 Vols.]. Moscow, Izd-vo gosudarstvennoy biblioteki SSSR imeni V.I. Lenina, 1962-1976, vol. 5. 300 p.

Schwanwitz M. Die Teutsche Grammatica. Aus unterschiedenen Auctoribus zusammen getragen und Der Russischen Jugend zum Besten heraus gegeben von dem Informatore der Teutschen Sprache bey dem St. Petersburgischen Gymnasio. Nemetskaya grammatika iz raznykh avtorov sobrana i rossiiskoy yunosti v polzu izdana ot uchitelya nemetskago yazyka pri Sankt Peterburgskoy gimnazii [German Grammar Compiled from Works of Different Authors and Published for the Benefit of the Russian Youth by a Teacher of German in Saint Petersburg Gymnasium]. Saint Petersburg, Tipografiya Akademii nauk, $1730.13 \mathrm{p}$.

Charmyntes, Hrsg. Die deutsche Grammatica, Aus Unterschiedenen Autoribus zusammen gebracht... Berlin, 1713.120 S. 


\section{Information about the Authors}

Nataliya V. Kareva, Candidate of Sciences (Philology), Senior Researcher, Institute for Linguistic Studies of the Russian Academy of Sciences, Tuchkov Lane, 9, 199053 Saint Petersburg, Russia, natasha.titova@gmail.com, https://orcid.org/0000-0001-6861-6512

Evgeniy G. Pivovarov, Doctor of Sciences (History), Leading Researcher, Saint Petersburg Branch of the Institute for the History of Natural Sciences and Technology of the Russian Academy of Sciences, Universitetskaya Emb., 5, 199034 Saint Petersburg, Russia, pivovaro@mail.ru, https://orcid.org/0000-0001-8701-9684

\section{Информация об авторах}

Наталия Владимировна Карева, кандидат филологических наук, старший научный сотрудник, Институт лингвистических исследований РАН, пер. Тучков, 9, 199053 г. Санкт-Петербург, Россия, natasha.titova@gmail.com, https://orcid.org/0000-0001-6861-6512

Евгений Григорьевич Пивоваров, доктор исторических наук, ведущий научный сотрудник, Санкт-Петербургский филиал Института истории естествознания и техники им. С.И. Вавилова РАН, Университетская наб., 5, 199034 г. Санкт-Петербург, Россия, pivovaro@mail.ru, https://orcid.org/0000-0001-8701-9684 